\title{
ENVIRONMENTAL VOLATILITY AND EFFECTIVENESS OF EDUCATIONAL PLANNING: THE NIGERIA EXPERIENCE
}

\author{
Mary Oluwatoyin Ajani \\ University of Ibadan \\ toyin_ak2002@yahoo.co.uk \\ toyin_ak2002@outlook.com
}

\begin{abstract}
The school structures in old times used to be situated in an isolated environment because it is believed that such serenity was conducive for learning. Unfortunately those old outskirt has become city which is now vulnerable to interference in a way that things which were not experience in school areas before have become the norms. Recently, Nigeriahas witnessed unexpected volatility which has affected her education system. Attacks such as kidnapping, suicide bombing, insurgencies, school-based violence, banditry, religion crisis, hoodlum attacks, break-in and vandalism of school properties by hoodlums and drug addicts to attacks involving burning schools or killing, injuring, kidnapping, detaining or torturing students, teachers and academics.Pandemic such as Ebola and covid-19represents a huge threat to security as it usually claim lives and destroys few available school infrastructures. The consequences which leads high drop-out rates, reduction in enrolment and lower teaching quality worsen effective educational planning and sustainable national development such that if pro-active measures are not put in place, long term danger awaits the quality of labour force and human capital needed for a sustainable economy. Ensuring education continuity and safe school in a volatile environment is of a great concern to education planners such that such either internal or external influences that contributes to unstable or violent environment will not affect the effectiveness of planning education (Nwosu et al., 2019; GCPEA, 2017; Akintunde and Musa, 2016).To achieve the goals of education, it has to evolve in an environment free of violence as learning rates fluctuate with the volatility of the environment. Disruptions in education can reduce the likelihood that students will return to school, even when they re-open, and can, in the long term, impact individual earnings and the country's ability to rebuild its national economy.
\end{abstract}

Keywords: Environmental volatility, Educational Planning 


\section{Conceptual Clarification}

\section{Educational planning}

The success of any educational system depends on effective planning and implementation. Planning is a term that is applicable in all spheres of life. Planning is the process of examining the future and drawing up appropriate actions for achieving specified goals and objectives. It means working out in broad outline the things to be done and the procedures for doing them to accomplish set purpose (Akpan, 2000). The researcher also viewed educational planning as the application of rational systematic analysis to the process of educational development with the process of making education more effective and efficient in responding to the needs and goals of the students and the society. The researchermaintained that educational planning should take into account any future changes that may want to affect existing plans hence the need for flexibility. Nwankwo (1981) explained that educational planning is a process of preparing a set of decisions about educational enterprise in such a way that the goals and purposes of education will be sufficiently realized in future with the available resources.According to Ololube (2013) educational planning is a concise and deliberate attempt, through organized and continuous processes to identify the different elements and aspects of the educational industry. It helps us in determining the present state and interaction, hence projecting them throughout a given period of time. This is done by analyzing, formulating, implementing and controlling the actions that have evolved to attain the desired aims and objectives of education.

A plan is described as efficient if the resources put into it are sufficient in meeting the stated objectives. Ololube (2013) opined that it is important for educational production to be both effective and efficient so as to properly guide the internal and external changes in the school as it utilizes the educational resources available. Unfortunately resources are scarce in a developing country like Nigeria where education has to compete with other sector for the allocation of funds within limited resources and this makes it imperative for educational planners not to be wasteful hence plan effectively for even unforeseen circumstances that may affect education for all(Edem,2004; Edame,2015). They further observed that the effectiveness of education depends on Strategic planning which deals with macro issues emphasizing what the organization should do. It focuses on the educational system and its environment as consisting of many subsystems interacting between themselves and the environment.

Educational planning in Nigeria reflects the five main national objectives as stated in the second National Development Plan (1970) which was endorsed by the government as the necessary foundation for the National Policy on Education (1981. p. 7, FRN, 2004). These five main objectives include the building of:

- A free and democratic society;

- A just and egalitarian society;

- A united, strong and self-reliant nation;

- A great and dynamic economy;

- A land of bright and full opportunities for all citizens

If these stated national objectives are strictlypursued, then the quality of instruction at all levels will be oriented towards inculcating values such as freedom for the individuals to make national educational decisions, equal educational opportunities for all citizens at the primary, secondary and tertiary levels of educational, respect for the worth and dignity of individual 
citizens, respect for the dignity of labour, a healthy moral and spiritual development of individuals and a sense of responsibility to work together for the common good of the society. Since Educational planning in Nigeria covers all levels of education primary, secondary and tertiary therefore eachlevel requires different modalities of planning for skillful execution (Edame, 2015).

\section{Types of Educational Planning in Nigeria (Edame, 2015; Amadi, 2019; Akpan, 2020)}

Educational planning in Nigeria is dated back to the missionary and colonial period of Lord Lugard in the early 1950. The first educational policy in Nigeria was during the former Western Region 1952. The regional government proposed the introduction of free education to come into effect in January, 1955. To make this proposal succeed, the government proposed a large scale training of teachers, expanded the existing teacher training Colleges and purchased adequate equipment for the proposed schemes. Several planning committee were set-up to work out details for effective implementation of the plan. The scheme was implemented as scheduled. The scheme however, ran into unforeseen difficulties. One of these was the inadequacy of teachers which led to poor quality of teaching and falling standards of education. There was an upsurge in the number of pupils since education was free and compulsory. Equipment was inadequate; Schools were not properly monitored because the number of supervisors was few compared available pupils. After six years of operation, the plan was reviewed with a view to detecting errors in planning and making necessary corrections. It was indeed clear that the planning was faulty.

The second policy was introduced in the former Eastern Region which has been described by Ozigi and Canham (1979) as "hastily prepared". The poor planning at the initial stage led to shortage of teachers, equipment, buildings and other essentials. Like the government of Western Region, the government of Eastern Region set up the Dike committee, which later found out that the government was spending over $30 \%$ of its national resources on education, and that most of the budget on education was exhausted on primary education alone. The committees therefore recommend qualitative rather than quantitative education. A compromise was then reached whereby a three year non-fee paying system and a three year fee paying system based on the estimated local distributions was adopted by the government.

The third educational policy was that of Northern Nigeria whereeducational planning between 1962 and 1968 was guided by Ashby commission's Report which Recommendation that:-

a) $10 \%$ of all children completing primary education should proceed to secondary education.

b) $30 \%$ of those completing WASC (West African School Certificate) should be admitted into Institutions of higher learning including university.

c) $25 \%$ of all children should complete primaryeducation.

The recommendations preceded the introduction of Universal Primary Education UPE). Again, planning was not effective and this adversely affected the scheme, so by $1967,11 \%$ overall enrolment was attained. The demand for enrolment into secondary school however, exceeded Ashby Commission'sestimate by 1967 when $11.4 \%$ was recorded instead of the $10 \%$ estimated by the commission. From this time to 1976, the six universities then in 
existence (Ibadan, Lagos, Ife, Benin, Ahmadu Bello and Nsukka) could not even cope with the number of candidates aspiring to gain admission into the university.

The fourth phase of educational planning was the Universal Primary Education (UPE) schemes launched in September 1976 by the Federal Government. According to the announcement by the Federal Government, the UPE became compulsory in 1979. Barely one year after the scheme had become operative, it become clear that the planning was faulty. Some of the major difficulties included the shortage of teachers, classroom space, equipment, funds to purchase the essential materials. While some of the schools were overenrolled, others were under-enrolled. The whole nation was dotted with primary schools that were poorly maintained, some abandoned. The Federal Government started shifting some of the financial burden onto the state and local governments, and even to the communities in which these schools weresituated. It was again clear that he planning was faulty and short-sighted. It was not based on adequate statistics and demographic data, and was not backed up with enough teachers, enough teaching materials, buildings and funds to pay staff salaries.

The fifth educational planning and policy in Nigeria was the introduction of the 6-3-3-4 system of education in 1982. This coded numeric observation means that children will spend six years at the primary education level. Six years at the secondary, but the secondary years will be divided into three years of junior secondary and three years of senior secondary. The last four years are expected to be spent in the university (a tertiary level of education. The 63-3-4 system of education in theory, places a central emphasis on pre-vocational education and academic in order to provide the needed technical manpower. It also aims at providing avenue for those not academically inclined to branch off into a vocational school where they are more likely to implement their talent (NPE, 1981. p. 17-18). Little preparation was made regarding the provision of the 6-3-3-4 system into the most appropriate educational programmes and consequently the most appropriate occupations ultimately. How teachers for the primary schools will be trained was not specified in the 6-3-3-4 system if the teacher grade two institutions would be phased out or not. It is likely that the drop-out rate will exceed the educational provision made to cater for them (Edame, 2015)

\section{The 1999 Education Plan: The Universal Basic Education (UBE)}

The Universal Basic Education (UBE) programme was launched on the 30th September, 1999 in Sokoto, Sokoto state by President Olusagun Obasanjo. The UBE Act, 2004 made provision for basic education in Nigeria to include Early Child Care Development and Education (ECCDE), primary and junior secondary. The responsibility of financing the basic education rests on the Federal, state and local governments.

The specific objectives of UBE scheme are to;

1. Develop in the entire citizenry a strong consciousness for education and a strong commitment to it vigorous promotion

2. Provide free, compulsory universal basic education for every Nigerian child of school going age.

3. Reduce drastically drop-out rate from the formal school system through improved relevant and efficiency 
4. Cater for drop-out and out-of-school children/adolescents through various forms of complementary approaches to the provision and promotion of basic education

5. Ensure the acquisition of the appropriate level of literacy, numeracy, manipulative and life skills as well as the ethical, moral and civic values needed for laying the foundation for life long learning.

This education plan for Nigeria is aimed at eradicating illiteracy, ignorance and poverty as well as stimulating and accelerating national development, political consciousness and national integration. This plan can rightly be described as the Nigeria's strategy for the achievement of Education for All (EFA) and the education related millennium development goals. The objectives of the basic education indicate that the programme is a nine-year basic education programme that covers 6 years of primary and 3 years of junior secondary education. Despite the expectations from the Universal Basic Education, the implementation of the programme is facing serious setbacks such as inadequate qualified teachers especially in junior secondary levels, inadequate classrooms for teaching and learning, insufficient funds to run the programme.

\section{The 4 -year Strategic Plan for the Development of the Education Sector, 2011-2015}

The Federal Republic of Nigeria (2013) lunched the 4- year strategic plan for the development of education sector.This education plan focused on tackling the challenges hampering the Nigerian education system from playing its role in national development.This transformation agenda of President Goodluck Jonathan addresses six focal areas

(1) Strengthening the institutional management of education.

(2) Access and equity

(3) Standard and quality assurance.

(4) Teacher education and development

(5) Technical and vocational education and training

(6) Funding, partnership and resource mobilization

The 4-year strategic education plan was an attempt to implement strategies that would make education more functional and beyond schooling where emphasis is on certification. The emphasis on technical and vocational education and training was necessary in order to provide pupils/students with the type of education that can make them self-reliant and to eradicate poverty. In order to achieve the goals of the 4 -year plan, the curriculum of the 9-year basic education, the National Policy on education and the curriculum of teachers' training were reviewed. The Early Child Care Development Education was institutionalized. There was also the distribution of instructional materials to schools, phased rehabilitation of Federal Unity Colleges, Need Assessment of Public Tertiary institutions and promotion of technical and vocational education and training.

\section{The 2016-2019 Strategic Plan for Education}

The 2016-2019 plans aimed at repositioning the Nigeria's education system to play a central role in the Federal Government's philosophy of change. The plan tagged "Education for 
Change" is focused on strengthening institutional structures and creating innovativestrategies aimed at revamping the education sector. The aims of this education plan as highlighted by Abdulsalam (2016) cited in Akpan (2020) included

1. To provide the needed direction to chart a course towards ensuring theprovision of inclusive and equitable education.

2. To provide life-long learning opportunities for all.

3. To promote technical and vocational education and training (TVET).

4. To promote accountability and transparency in government.

5. To promote public-private partnership and collaboration with donors tofill funding gaps.

6. To provide the type of education Nigeria needs to meet the target of thesustainable development goals.

7. To provide functional education as a leeway out of youth unemployment.

However, this strategic education plan recognizes paucity of funds as amajor challenge for the development of the education sector. Perhaps, this isone of the reasons the plan is aimed at promoting public-private partnership andcollaboration with donor agencies to fill the funding gaps.

The purpose of educational planning is effective implementation. Olubor (2004) observed that there are two types of education planning in vogue in many parts of the world, namely: strategic and operational planning. Operational planning focuses on the present resources and operational problems to ensure that the goals are attained. It is any planning carried out at the local or the institutional level. It is concerned with measurable and verifiable objectives. Strategic and operational plans are complementary; for instance while strategic planning ensures that the right thing is done, operational planning is to ensure that the system is doing things right. Olubor (2004) also remarked that such plans should take any of the following forms:

$>$ Adaptive Educational planning: This is a plan undertaken principally because of externally induced development. That is plans made to adapt to the new condition.

$>$ Contingency Educational Planning: This is an approach aimed at creating conditions whose effect can be adsorbed at minimum cost of in convenience.

> Manipulative Education planning: when a situation develops a plan relying on various types of instruments is effected to gain an advantage of the situation. For instance, if revenue suddenly decreases, due to market forces, various means of production should be devised to save the educational situation.

\section{Concept of Environment}

The term environment comes from the French word "environ" and means everything that surround us. Environment includes water, air and land and the interrelation ships which exist among and between water, air and land and human beings and other living creatures such as plants, animals and microorganisms (Kalavathy, 2004).Environment according to 
encyclopedia is the social, material and non-material conditions of man's existence, development and activity. It encompasses the socioeconomic system as a whole which includes an individual's immediate surroundings such as family, work, school and other associations. The environment has decisive influence on the formation and development of personality. The meaning is more understood in the context in which it is itself used.This is the reasonSingh (2006) in Kingsley (2018) wrote that environment gives explanation to the existence of man since man cannot be understood in isolation thus, environment is the sum total conditions for the existence of living things. All of the external factors, conditions, and influences that affect an organism or a community. Also, it is everything that surrounds an organism or organisms, including both natural and human-built elements. Kingsley, 2018 further identified three types of environment which are,

Physical: This refers to geographical climate and weather or physical conditions where an individual lives. The human races are greatly influenced by the climate.

Social: This includes an individual's social, economic and political conditions where he lives. It consists of the moral, cultural and emotional forces which influence the life and nature of individual behaviour.

Psychological: Although physical and social environments are common to the individual in a specific situation, yet every individual has his own psychological environment, in which he lives. The Psychological environment enables us to understand the personality of an individual. The person and his goal form psychological environment.

\section{School Environment}

A safe environment is necessary for effective educational planning and to learners since students spends most of their time at school. The school environment can determine to a large extent the stability of the student's mind for academic readiness.According to Mick (2011), School Environment means the extent to which school settings promote student safety and student health, which may include topics such as the physical plant, the academic environment, available physical and mental health supports and services, and the fairness and adequacy of disciplinary procedures, as supported by relevant research and an assessment of validity.According to Ojukwu (2017), citing Obi et al., (2004) school environment connotes all human and material resources available in the school, in which a child can see, hear, touch, smell, taste, feel and respond. Miller and Cunnighan (2011) in Ojukwu (2017) also added that the academic dimensions of the school environment include the quality of instruction given to the students and the teachers expectations for good achievements from students. The school environment in Nigeria is full of hazards resulting to man-made disasters that made students vulnerable. This disrupts learning after which some never return to school, have psychological impacts on students, damage school infrastructures and affects quality of education

\section{Vulnerable Environment}

Vulnerability is a concept widely known and discussed within global environmental change and hazards literature.Ole (2012) defines vulnerability is a measure of the extent to which a community, structure, service or geographical area is likely to be damaged or disrupted, on account of its nature or location, by the impact of a particular disaster hazard.Nkwunonwo (2015)viewed as lack of capacity and resources to effectively withstand a shock or stress, the 
degree of susceptibility of a feature which is determined by exposure and lack of coping capacity. He stressed that the hazard to which a feature is exposed, its sensitivity and the lack of coping capacity and resilience of the system experiencing the hazard are significant factors which highlight vulnerability. Vulnerability is a function of the character, magnitude, and rate of climate variation to which a system is exposed, its sensitivity and its adaptive capacity. School environment can be vulnerable or sensitive to pollution, interference, natural disaster, environmental hazards such as flooding or man-made disaster. According to James and Barry (2004) vulnerability has two major perspectives: biophysical and social. The former is viewed as being determined by the nature of the physical event to which the human system is exposed, the likelihood or frequency of occurrence of the event, the extent of human exposure, and the system's sensitivity to the impacts of a particular event. The later focuses primarily on the human determinants or drivers of vulnerability, namely, the social, political, and economic conditions that make exposure unsafe or challenging. Meaning that hazards and disasters were not a result of physical events alone, but were also greatly influenced by the social, economic, and cultural conditions.

\section{Peculiar Environment}

An abnormal environment that is characterized with noise, physically challenged, unstable policy and other features that are not found in a decent environment is peculiar. It has counterstrike variables of environment such as political, economic, technological, social, cultural and legal influences. According to Akinwunmi and Antony (2020), Nigeria is a peculiar environment for effective education planning. The education system in Nigeria is harassed by systematic dysfunction traceable to factors which includes gross underfunding and bureaucratic bottleneck that thwart the expertise when appointed into offices that have direct influence on education as such Nigeria is a peculiar environment.

\section{Volatile Environment}

Volatility according to Tom (2020) is dealing the challenge to match available resources to unknown risk due to unstable changes that are hard to predict and can shift unpredictably and without warning. It is planning education from perception of Volatility, Uncertainty, Complexity and Ambiguity (VUCA). Business dictionary defines volatile environment as an unstable, varying or inconsistent atmosphere frequently between extreme high and low. Wikipedia buttressed that volatile environment are environment that changes unexpectedly due to external or internal influences and could suddenly become dangerous. According to Collins dictionary a situation that is volatile is likely to change suddenly and unexpectedly. Environment implies all external or internal elements that have the potential to affect the organization. Today the environment is changing so fast such that it creates uncertainty and becomes increasingly volatile thus poses a great threat for any organization. Meanwhile others view a volatile environment as an opportunity for any organization to innovate. Based on these considerations, this paper highlights external and internal factors that influences a volatile environment and show how they make up threats or opportunities on the effectiveness of educational planning.

\section{Issues withEnvironmental Volatilityand Education Planning In Nigeria}

\section{Insecurity}


Insecurity is a threat to learning as No country can achieve the educational goal of sustainable in the face of widespread insecurity. Nigeria is faced with various forms of violent insecurity challenges ranging from the civil war, election related mayhem, riots and protests, militancy, insurgency and herdsmen/farmer clashes.According to Akintunde and Musa (2016) security is perceived as a basic human need that contributes to effective learning. A safe school is one that fosters peaceful, positive or cordial relationships among students, teachers and administrators. However, the rise of Bokoharam sect created an new dimension to Nigeria`s insecurity problems. The country has been embroiled since 2009 in an armed conflict with the Islamist insurgency group Jama'atu Ahlis Sunna Lidda'Awati Wal-Jihad, popularly known as Boko Haram. This group has killed an estimated 20,000 and displaced over 2.2 million in the wider Lake Chad region (GCPEA, 2018). The main tenet of this deadly group is that western education is evil and should be abhorred. This ideology has gained notoriety for its repeated attacks on schools and universities, as well as teachers, administrators, and students, wreaking havoc on an already fragile education system. The operations and activities of Bokoharam sect against education came to limelight following the abduction of 276 students of Government Girls College; Chibok such this major attack has led to many other cases afterwards. Iheamnachor (2015) and Adesulu (2019) also reported that five secondary school teachers were abducted at gunpoint from a school in Rivers State which left the people in the area in total fear and tension. Cases of kidnapping of teachers and students (Lagos Junior Model College, Igbonla), killing of students and their teachers, Yobe school attack of burning down schools. Recent statistics showed that about 2,295 teachers have been killed and 19,000 others displaced in Bornu, Yobe and Adamawa States between 2009 to 2018, while an estimate of 1,500 schools had been destroyed since 2014, with over 1,280 casualties among teachers and students. All these attacks indicate vulnerability of schools such that number of school enrolment in the areas prone to these attacks have already declined considering percentage change in year 2012-2016 federal ministry of education 2016.

Considering the importance of education and the need for adequate security of the school environment, it seems that no one is advocating towards the issue of school security in Nigeria though government claimed that it has defeated Boko Haram repeatedly yet the group continues to carry out attacks on schools and abductions. This lack of proactive security planning increases recurrent and multiplicity of school related insecurity challenges hence the need to adequately secure vulnerable school environment cannot be over-emphasized. Insecure school environment affect the learning of children, triggers traumatic disorder and toxic stress that negatively affects learning. The United Nations Children's Fund (UNICEF, 2017) estimates that more than 1,400 schools have been destroyed, damaged, or looted primarily in the northeast, and more than 600,000 children have lost access to education. General school attendance and enrolment are equally affected as parents pull their children out of schools while in some extreme cases, insecurity has led to closure of schools. In the end, educational attainment in terms of quality of graduates and manpower suffers which impinge on overall national development aspirations Akintunde and Musa (2016).According to a study carried out by GCPEA (2018)attacks on education create a ripple effect, setting in motion a range of negative impacts such as loss of education, early marriage, early pregnancy, and stigma associated with sexual violence and children born from rape, all of which can dramatically affect female students' future. The study also found that at the peak of the conflict, Boko Haram also used schools for various military purposes, including to hold and execute captives, and as barracks for insurgents. This further contributed to parents' and students' fears about the safety of sending their children, and especially their daughters, back to school after the insurgents had departed. 
Despite the reported military successes and endorsement of the Safe School Declaration in May 2015 the security situation in the northeast of Nigeria remains volatile. While Boko Haram has been pushed out of most towns that were previously under its control, the surrounding areas often remain too insecure to allow movement outside the town centers or to justify return of the civilian population.The Education in Emergencies Working Group Nigeria (EiEWGN) conducted a Joint Education Needs Assessment (JENA) in the fall of 2017, which stated that:

Security remains a challenge, with the increasing number of suicide bombings, attacks on villages, IDP settlements and soft targets and other asymmetric attacks. This prevents returns and access to livelihood opportunities thus increasing dependency on humanitarian aid. In October 2017 alone, more than 50 people were killed, dozens more injured and properties destroyed in ambushes, suicide attacks or raids on villages. At least two local government areas (LGAs) remain inaccessible and several roads closed or requiring military escort, making humanitarians intervention more difficult.

The education system in Northeastern Nigeria was already fragile before the conflict with Boko Haram began, with significant numbers of children never attending school and large numbers dropping out without completion of secondary school. There were significant regional disparities in educational attainment, with children from the north much less likely to attend school. Theconsequences of these on education in northeastern Nigeria cannot be overemphasized. Even after the schools were officially allowed to reopen in these areas, most students could not return because of ongoing insecurity. As of September 2017, UNICEF reported that the conflict had destroyed or damaged an estimated 1,400 schools, and that 57 percent of all schools in the northeast remained closed due to insecurity, over 600,000 children have lost access to education in Borno state alone. 2,295 teachers were killed by Boko Haram between 2009 and 2017. Furthermore, over 19,000 teachers are estimated to have fled the region due to security concerns. As a result, many children have no access to education whatsoever, or can only be accommodated in classes with an overwhelming number of children per teacher.

\section{Causes of Insecurity in Schools}

School location: The location of some secondary schools on the margins of towns or even in remote areasbetween towns makes them particularly vulnerable to attack. Many secondary schools in Nigeria are boarding schools. These schools are often located on the margins of towns or even in remote areas between towns so that several towns can share a single school. While some students live in the nearby towns, most students live in dormitories on campus. Schools should not be in the bush but located in towns where protection can be provided.

Failure to Learn Lessons from Past Attacks: Nigeria government did not appear to have a sense of urgency about improving schools' security. This affects our pro-activeness to securing the school environment. Some of the schools are not fenced, GCPEA reported that their schools had no or wholly inadequate security measures in place, except for an elderly guard or two, and that no additional measures were introduced, or protocols established, to respond to the deteriorating security situation.

Unequal Access to Education: This can cause tension between groups, and between citizens and the state. When schools are viewed as extensions of the state, against which there are grievances, they can become vulnerable to attack. 
Vandalisation: Bulgary and vandalisation happens where devises are made available but there are cases of theft such that those equipment and technological devices were carted away or stolen. This however calls for effective security system within the school premises. Security outpost should be built within or around schools premises.

\section{Manmade and Natural Disaster}

Schools are faced with dynamic environmental change of which educational activities must be adapted not only to reduce the change itself, but also to respond to the effects of that change. Natural or manmade Disasters are not random and do not occur by accident, they are the convergence of hazards and vulnerable conditions that poses challenges to educational planning as they erode hard earned gains of educational progress, as well as infrastructure and technological development. Being aware about possible hazards is an important aspect in locating schools unfortunately many schools in Nigeria is vulnerable to natural or man-made disaster. The Millennium Declaration recognizes the risk to development stemming from disasters and calls on the global community to "intensify our collective efforts to reduce the number and effects of natural hazards and man-made disasters as noted by UNEP (2015). Environmental degradation, settlement patterns, livelihood choices and behaviour contributes to disaster risk, which in turn adversely affects human and educational development. The poorest among the South-south, Ijaw's, Ilaje's in Nigeria are the most vulnerable to disasters because they are often pushed to settle on the most marginal lands and have least access to prevention, preparedness and early warning. In addition, many of them live in rural villages or earn their livelihoods and are also the least resilient in recovering from disasters because they lack support networks, insurance and alternative livelihood options (UNEP, 2015).There is a strong causal relationship between poverty, a degraded environment and higher disaster risk. People who live in marginal or environmentally degraded areas often struggle on a daily basis to survive and are unable to cope with any additional stress factors. Limited livelihood alternatives, competition over scarce resources, weak governance structures and lack of access to healthcare and other services can compromise a community's ability to respond to and recover from a hazard event. Events such as floods is designated as 'hazardous' because it threaten human communities and valuable elements. Nkwunonwo (2015) maintained thatLagos flood of July $11^{\text {th }} 2011$ has convinced individual that the society and education planners should be prepared to cope with such disasters in the future. The flood affected more than 10 thousand people with deaths exceeding 100 and a range of damage including public infrastructure like roads, bridges and schools. Flood can be caused by human encroachment which includes lack of good drainage system, clustered buildings in unapproved areas, building in areas below sea level, sand-filling swampy areas to construct buildings.

\section{Challenges of Educational Planning in Nigeria}

Educational planning in developing countries such as Nigeria is compounded by a number ofconstraints. There is a popular saying that "he or she who has failed to plan has planned to fail". The success of any educational system hinges on proper planning and lack of effective planning poses a significant obstacle to the advancement of education across the country. Planning of human and material resources has evolved to guide the allocation and utilization of educational resources in the school systems. Such planning is required to arrest areas of wasted resources and to make educational production more successful. Financial constraints and lack of financial resources causes the abortion of planned projects. The budgetary allocation available for educational planning in Nigeria is nothing to write home about. Funds provide for education planning is too small for proper planning to take place. The issue of 
inadequate or reliable and valid statistical data to serve as a basic for planning constitutes a serious constraint to educational planning. Effect of political instability on educational planning is such that it influences control over educational planning. A lot of plans cannot be fully implemented as the change of government usually introduces a new package on educational planning and disrupts the previous plan as a whole; no continuity. Inadequate Skilled Personnel hinders efficient planning productivity and performance; many educational planners in Nigeria are not professionals. Another serious problem in the planning of education in Nigeria is the lack of attention paid to emerging technological innovations planning mechanisms. The success of Nigerian education planners depends upon their ability to identify and respond to $21^{\text {st }}$ century technological changes in other to elevate their planning output.

\section{Review of Empirical Studies}

Nwosu et al., (2019) carried out a study on insecurity and the Nigeria school system. It focused on the issues of school threat using a vector autogressive model and utilizing annual data spanning between 1981 and 2016. The result showed that school security will attract more children to enroll in schools. Based on the findings, it was suggested that the frequent attacks on the school system should be securitized and placed on red-alert for the state actors to devote adequate attention and resources towards ameliorating this menace. In a related study conducted by Akporehe (2019) on assessment of pre-service teachers' preparedness towards security challenges in primary schools in Delta State, a descriptive survey research was carried out with a sample size of 300 . The findings of the study showed that pre service teachers were not prepared for security challenges in schools. It was recommended among others that the curriculum of pre-service NCE teachers should be reviewed to accommodate security challenges in Delta state. Amadi (2019) examined education policy changes and effective administration: implications for Senior Secondary Schools in Rivers State using a descriptive survey design with 273 sample size. The findings of the study showed that educational policy changes had impacted positively on administration of Senior Secondary Schools in terms of curriculum and students ${ }^{\text {ee }}$ academic performance. Based on the findings, it was recommended that principals and school administrators should be incorporated in education policy formation and implementation. Furthermore, Akinwunmi and Anthony (2020) looked at Managing Education in a Peculiar Environment: A Case Study of Nigeria's Response to COVID-19. They highlighted the adverse effects of pandemic on the Nigerian education system and also evaluated the response of the government and private school owners in addressing the challenges of covid-19 on education in Nigeria. They found that with or without the COVID-19 pandemic, the Nigerian society is a peculiar environment owing to the systemic dysfunction observed in every sector of the nation. Nkwunonwo (2015) researched on massive impact of flooding on urban residents through critical discussions regarding social vulnerability and its assessment in relation to addressing the challenges of flooding in Lagos, Nigeria. The study concludes with some recommendations that key stake holders will find quite desirable towards flood risk reduction in the area. Ojukwu (2017) investigated the effect of insecurity of school environment on the academic performance of secondary school students in Imo state, Nigeria with a total of 1000 respondents. Major findings revealed that insecurity of school environment significantly affects the academic performance of secondary school students while students' gangsterism, smoking of Indian hemp, abusing other hard drugs, cult and related violent activities were some of the factors that constituted insecurity of the school environment. He recommended that owners of 
schools and other stakeholders in education should take bold steps to fence and protect school environments from intruders to ensure safety of the students.

\section{Implications of EnvironmentalVolatilityto Education Planning}

Safety of any Nigerian students in school is not a luxury but a necessity that requires urgent attention of stakeholders in the education sector to achieve national security. Insecure environment creates ultimate exclusion when students and staff are killed because schools are unsafe. When instruction time is lost, quality of education drops especially when there is no plan for alternative location and students are denied continuous schooling, many will not be able to catch up and will drop out permanently. Educational funding is affected due to damages beyond repair. There will be need for re-investment which many times will be higher due to inflation. Students lose their sense of continuity in education. Planning education for an environment that is vulnerable to attacks may be challenging to. However considering the grave consequences on the students and Nigeria at large, one would see the need for all hands to be on deck. Programs to Improve Access to Education must be of prioritized, Provision of non-formal education opportunities for IDP children who are out of school with material supportnecessary to facilitate the enrollment of children. Construction of temporary learning centers in safe environment, establishment and the rehabilitation of preexisting classrooms/schools. Awareness/publicity on the importance of education and encourage parents to enroll their children. Where possible help mainstream children into the formal education system and provide alternative delivery of educational instructions and teaching. This can be achieved via on-line classes, telecast and radio broadcast to provide literacy and numeracy lessons. Train teachers and students on security, crisis management, early warning signs, and protective measures. Teach northerners how to read quaran and gradually introduce western education.

Furthermore, there should be Establishment of education policies and programs that reduce the causes of tension between groups and that increase social cohesion across groups contributes to building peace, reducing the likelihood of attacks on education and military use of schools in the future. Organize Conflict-sensitive programs and policies that take note of problems related to languages of instruction, bias in access, staff recruitment and deployment, and curriculum content. Education planners should develop curriculum materials and approaches that promote safety, resilience, and social cohesion, thus promoting equal access to relevant quality education for all identity groups. They should seek to ensure the continuation of education during crisis, support the reestablishment of educational facilities, guide against attacks on educational facilities. Study the physically challenged culture i.e. their way of life, problems and needs in order to develop, adopt and promote 'conflictsensitive' approaches to education. Disasters can be substantially reduced if people are well informed and embrace a culture of prevention. A school disaster safety or crises response team should be proposed and implemented to combat any disaster. Refugees face a challenging situation in respect of access to education. They are resident in a country of their own yet disconnected from their country's educational provision. There have been instances of political, legal or administrative obstacles to refugee education as well as practical problems of access.

Boko Haram attacks on civilians and the related armed conflict continued to cause refugee influxes to neighboring countries. The refugee-hosting areas do not have adequate capacity in terms of livelihoods and social and basic services, which in turn has an environmental and economic impact. There are significant constraints for refugees and their hosts in accessing 
quality education in a safe learning environment. Some children who are internally displaced as a result of flood and other disaster are more disadvantaged than refugees since they lack protection and assistance. Feelings of exclusion as well as struggle for survival increase the out-of-school children in Nigeria. Education has a potential to restore a sense of normalcy, build a stable future for these survivals. Schools need to be constructed or rehabilitated, qualified teachers should be deployed in sufficient numbers, setting up pre-school activities, strengthening primary education, facilitating access to basic and secondary education, vocational training, creating literacy opportunities for all and strengthening community participation through awareness raising campaigns on the importance of formal education should be the priority of planning education for refugees and internally displaced people.

\section{References}

Abdulsalam, K.(2016). Federal Government unveils strategic plans for improved education. Available online: www.newsexpressngr.com Retrieved 29 March, 2017

Adesulu, D. (2019). Effects of insurgency attacks on education in the North East. Vanguard News. Retrieved from www.vanguardngr.com, May 9.

Akintunde, O and Selzing-Musa, G. (2016). Environmental insecurity and the Nigerian child's learning: coping strategies. Asia Pacific Journal of Multidisciplinary Research. 4(1),13-17.

Amadi, O. (2019). Educational Policy Changes and Effective Administration: Implications For Secondary Schools In Rivers State. International Journal of Innovative Development and Policy Studies 7(2):91-102, April-June, 2019, SEAHI PUBLICATIONS, 2019, ISSN: 2467- 8465.

Columbia. Retrieved on March 21, 2012, from http://ed.sc.gov/agency/ac/StudentIntervention-

Edame, G. E. (2015). Planning as an Instrument for National Development in Nigeria. Global Journal of Management and Business Research. Economics and Commerce Volume 15 Issue 4 Version 1.0 Year 2015.

Federal Republic of Nigeria, (2013). National Policy on Education. Lagos: Federal Ministry of Information.

Global coalition to protect education from attack (GCPEA), (2017). The safe school, a framework for action. http://www.protectingeducation.org 
Global coalition to protect education from attack (GCPEA), (2017). Implementing the Guidelines: A toolkit to guide understanding and implementation of the Guidelines for Protecting Schools and Universities from Military use during Armed Conflict.

Global coalition to protect education from attack (GCPEA), (2018). I will never go back to school. The impact of attack on education for Nigerian women and girls http://www.protectingeducation.org

Iheamnachor, D. (2015). Abductors of five teachers in Rivers demand 25m Naira ransom, Vanguard News. Retrieved from www.vanguardngr.com,April 16

JAMES, D. F., and BARRY, S. (2004). A Framework for Assessing the Vulnerability of Communities in the Canadian Arctic to Risks Associated with Climate Change. VOL. 57, NO. 4 (DECEMBER 2004) P. 389- 400

Kingsley, E. E. (2018). Elements of Environmental Studies. Samuel Adegboyega University, Ogwa, Edo State. 2: 177 - 188. https://www.researchgate.net/publication/328783669

Mick, Z. (2011). South Carolina School Environment Initiative. South Carolina Department of Education,Columbia. Retrieved on March 21, 2012, from http://ed.sc.gov/agency/ac/Student-Intervention-Services/documents/SCSchoolEnvironmentRFP-Nov2011.pdf

National Policy on Education (NPE), (1981). National Policy on Education, Federal Republic of Nigeria (Revised), Lagos - Nigeria. Federal Government Press.

Nkwunonwo, U. (2015). Relevance of Social Vulnerability Assessment to Flood Risk Reduction in the Lagos Metropolis of Nigeria. British Journal of Applied Science and Technology . January 2015, DOI: 10.9734/BJAST/2015/17518. https://www.researchgate.net/publication/276540727

Nwankwo, J. I. (1981). Fundamentals of Management Information Systems. Ibadan: Associated Book-Makers (Nig.) Ltd

Nwosu, C., Ukwunna, J., Ebokaiwe, C. and Ukwunna, G. C. (2019). Insecurity andthe Nigeria School System: The Securitization Option for Sustainable Development. https://www.researchgate.net/publication/334668277

Ojukwu, M. O. (2017). Effect of Insecurity of School Environment on the Academic Performance of Secondary School Students in Imo State. International Journal of Education \& Literacy Studies ISSN 2202-9478. Vol. 5 No. 1; January 2017. Australian International Academic Centre, Australia. URL: http://dx.doi.org/10.7575/aiac.ijels.v.5n.1p.20

Ole, O. A. (2012). Vulnerable Environments; Sensitivity Mapping and Protection.

Ololube, A. (2013). The Problems and Approaches to Educational Planning in Nigeria: A Theoretical ObservationPhttps://www.researchgate.net/publication/272709384 Mediterranean Journal of Social Sciences. 
Olubor, R. O. (2004). Planning in education system. In Nwegwu, N. A. and Nwagwa C.C (ed) Organization and administration of education: Perspectives and practices. Benin: Festa Printing Press Ltd.

Tom, J.H. (2020). Teaching and learning in a VUCA world.www.protectingeducation.orgwww.protectingeducation.org

United Nations Children's Fund (UNICEF), (2017). "Making Schools Safer and Students more Confident. https://www.unicef.org/nigeria/media_11644.html (accessed October $15,2017)$. 